\title{
Foundation in Law students' reading awareness of the case
}

\section{law genre [version 1; peer review: 1 approved with}

\section{reservations]}

\author{
Suhaila Abdullah (D), Sareen Kaur Bhar \\ Faculty of Applied Communication, Multimedia University, Cyberjaya, Selangor, 63100, Malaysia
}

V1 First published: 11 Jan 2022, 11:28

https://doi.org/10.12688/f1000research.73618.1

Latest published: 11 Jan 2022, 11:28

https://doi.org/10.12688/f1000research.73618.1

\section{Abstract}

Background: A text of different genre might pose a different problem to students and different genre requires different approach in understanding and comprehending it. Developing the expertise in reading legal texts at an early stage of learning will be very beneficial to the students of law. This study examines the level of preuniversity/foundation in law students' awareness for the case law genre, and the aim of this study is to investigate the extent of awareness of the case law genre among the foundation in law students.

Methods: Five students who were pursuing their study in the foundation/pre-university level were selected as the subjects in this study. Qualitative data were obtained through the think-aloud procedure and questionnaire which was administered after the thinkaloud procedure. The transcription of each student's verbal reports was scrutinised for evidence of genre awareness while the answers given in the questionnaire were used to support the findings of the study. Genre analysis of 4-Move structure was used to identify the students' level of awareness.

Results: The findings indicate that the students were aware of the case law genre. However, they displayed a mixed-level of awareness. Conclusion: It is hoped that this study can provide some insights into the reading behaviour of law students especially when reading case law. Knowing and understanding the case law structure is integral for law students, and analysing students understanding of reading case law can help both the students and English for Academic Purposes (EAP) educators.

Keywords

Genre analysis, reading skills, awareness, case law genre

\section{Open Peer Review}

Approval Status ?

1

$\begin{array}{lc}\text { version } 1 & ? \\ 11 \text { Jan } 2022 & \text { view }\end{array}$

1. Ina Suryani Ab Rahim ID, Universiti

Malaysia Perlis, Arau, Malaysia

Any reports and responses or comments on the article can be found at the end of the article. 


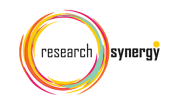

sing

This article is included in the Research Synergy

Foundation gateway.

Corresponding author: Suhaila Abdullah (suhaila.abdullah@mmu.edu.my)

Author roles: Abdullah S: Conceptualization, Data Curation, Formal Analysis, Investigation, Methodology, Resources, Validation, Writing - Original Draft Preparation, Writing - Review \& Editing; Kaur Bhar S: Writing - Original Draft Preparation, Writing - Review \& Editing

Competing interests: No competing interests were disclosed.

Grant information: The author(s) declared that no grants were involved in supporting this work.

Copyright: @ 2022 Abdullah S and Kaur Bhar S. This is an open access article distributed under the terms of the Creative Commons Attribution License, which permits unrestricted use, distribution, and reproduction in any medium, provided the original work is properly cited.

How to cite this article: Abdullah S and Kaur Bhar S. Foundation in Law students' reading awareness of the case law genre [version 1; peer review: 1 approved with reservations] F1000Research 2022, 11:28 https://doi.org/10.12688/f1000research.73618.1

First published: 11 Jan 2022, 11:28 https://doi.org/10.12688/f1000research.73618.1 


\section{Introduction}

Text genre awareness and recognising text types are an integral part of students reading process, as it can assist students in their academic and professional lives. As students, different text genre entails different approach to reading strategies. Law students are required to read extensively, and the reading materials include not only non-legal texts, but also specifically legal texts or legal genre. Law students being the novice readers of legal texts need to acquire and develop the specific reading skills at the early stage of their learning. Comprehending how genre is structured and organised will enable the students to intragenerically recognise and understand other texts within the same genre. ${ }^{1}$

Genre studies and analysis are a situated linguistic behavior study within an institutionalised academic or professional setting, as well as a study on the identification of the typical generic structure and linguistic characteristics of the genre itself. ${ }^{2}$ The main focus on genre analysis is on its analysis of generic structures and rhetorical functions such as 'moves', 'schematic' or 'generic' structure. Bhatia (1991) highlights four noticeable competence areas for students to develop: knowledge understanding of the code, acquisition of genre knowledge, sensitivity to cognitive structures and exploitation of generic knowledge. ${ }^{3-5}$ In the legal genre, Bhatia (1993) proposes four different 'moves' structure that commonly appears in a case law:

Move 1: Identification of the case

Move 2: Establishment of the case facts

Move 3: Arguments on the case facts

Sub-move I: Giving case history

Sub-move II: Presenting arguments

Sub-move III: Deriving ratio decidendi

Move 4: Pronouncing on the judgement

The 'moves' familiarity and awareness will allow the law students to hone their reading strategies and comprehend the case law better. Case law is among the major sources of law in common law system, and central to law students' curriculum. Christensen (2008) highlights that the earlier the students achieve the skills of reading judicial opinion (case law) effectively and efficiently, the better it is for the students to be more successful in their studies and their legal profession. ${ }^{6,7}$ However, reading case law is a huge challenge among the law students. Arrifin (2014) agrees that reading case law is a specific reading that requires law students to identify the material facts, the ratio and the issue of law, and to analyse the application of the legal principles in the judgments. ${ }^{8}$

As one of the universities in Malaysia that offers Bachelor of Law (Hons), Multimedia University (MMU) is the only private university with a Certificate in Legal Practice (CLP) exemption. MMU's Law programme is either 1+4 years or 4 years of studies depending on the entry requirement. The 1-year programme called Foundation in Law programme is a pre-university equivalent, and it serves as an entry point to Bachelor of Law (4 years) for students with Malaysia Certificate of Education (SPM), an equivalent to General Certificate of Secondary Education (GCSE) in England. The 1-year foundation is a 3-trimester programme system.

Acknowledging the significance of case law reading strategies among law students, and to better equip students with the expertise of reading as an expert, the study aims to:

1. Examine the level of foundation in law students' awareness of the case law genre.

2. Investigate the extent of case law genre awareness of the foundation in law students.

\section{Methods}

Study design and participants

A qualitative case study method through the think-aloud procedure ${ }^{9}$ was conducted in collecting the data. Participants selection was based on purposive sampling, ${ }^{10}$ and the criteria of achieving minimum grade A of their English SPM, studying law course and was in final trimester of foundation study, achieving an average 3.0 CGPA for the past 
2 trimesters, and having the ability to verbalise at least $80 \%$ of their thoughts. Based on the criteria and agreement to participate in the studies, 20 students were selected for the think-aloud procedure practice sessions.

From the practice sessions, five female students were narrowed down and selected as the participants of the study. Individually, the students recorded their think-aloud protocol procedure sessions within a 2-week time period. The students were categorised as Student 1, Student 2, Student 3, Student 4 and Student 5. Individually, each participant read the case law taken from The Malayan Law Journal ${ }^{11}$ (see Underlying data) ${ }^{12}$ and concurrently verbalised their thoughts loudly while reading the case law. The 10-structured post-questionnaire was administered immediately after the completion of the think aloud procedure (See Underlying data). ${ }^{12}$ All individual sessions were audio recorded and transcribed verbatim, and the post-questionnaire for triangulation purposes was given after they completed their think aloud protocol session. The think-aloud protocol transcription was coded, and then scrutinised for evidence of genre awareness based on Bhatia's (1993) 4-Move genre analysis, and the post-questionnaire was used to supplement the thinkaloud protocol.

\section{Ethical approval and consent}

Ethical approval (EA0682021) was obtained from Multimedia University. All 5 selected students were 18 years old, and their participations were voluntary, and anonymity was guaranteed. As the nature of the study is qualitative, all participants gave their oral consent in participating and contributing data for this study before each of the recording took place. They were given details on the nature of the study, and the needs to audio record their think-aloud protocol. All participants understood their required roles in the study, and that their data would be published in journals or conference proceedings. By agreeing to participate in the study, they conceded that they gave their consent.

\section{Results and discussion}

The coded think-aloud protocol transcription analysis revealed that the foundation in law students showed a mixed-level of genre awareness of the case law. Table 1 shows the comparison of the students' Moves with the Bhatia's case law Moves.

Student 1 showed awareness of the case law genre, but she did not fully identify all the moves required in reading a case law. She fully identified Move 1, and 4. However, she did not recognise Move 2 as the full judgement section was like the headnotes section. She only managed to complete the first part of sub-move I and II of Move 3 by partially identifying the case history, reasons and the judgement made by the judge in addressing the second question raised in the case law. She did not identify the ratio decidendi (sub-move III of Move 3) and displayed any other indication of identifying the other arguments raised. She merely read and commented without making any connection to sub-move II and III. She clearly identified Move 4 by identifying the held sections. She clarified the judgement using her own understanding and concluded on the final judgement given by the judge. The data collected from the post-questionnaire supported her behaviour, and she admitted that knowing the structure would help her in understanding the case law better. Furthermore, her main strategy in reading case law was identifying the case issues. Interestingly, she was the only student who was aware that she was using different reading strategies when reading case law compared to reading non-legal genre. She

Table 1. Summary of Moves in reading case Law in comparison with Bhatia (1993).

\begin{tabular}{|l|l|l|l|l|l|}
\hline Bhatia (1993) 4-Moves & Student 1 & Student 2 & Student 3 & Student 4 & Student 5 \\
\hline $\begin{array}{l}\text { Move 1: Identification of } \\
\text { the case }\end{array}$ & $\begin{array}{l}\text { Full } \\
\text { identification }\end{array}$ & $\begin{array}{l}\text { Full } \\
\text { identification }\end{array}$ & $\begin{array}{l}\text { Partial } \\
\text { identification }\end{array}$ & $\begin{array}{l}\text { Full } \\
\text { identification }\end{array}$ & $\begin{array}{l}\text { No } \\
\text { identification }\end{array}$ \\
\hline $\begin{array}{l}\text { Move 2: Establishment of } \\
\text { the case facts }\end{array}$ & $\begin{array}{l}\text { No } \\
\text { identification }\end{array}$ & $\begin{array}{l}\text { No } \\
\text { identification }\end{array}$ & $\begin{array}{l}\text { Full } \\
\text { identification }\end{array}$ & $\begin{array}{l}\text { Full } \\
\text { identification }\end{array}$ & $\begin{array}{l}\text { Partial } \\
\text { identification }\end{array}$ \\
\hline $\begin{array}{l}\text { Move 3: Arguments on the } \\
\text { case facts }\end{array}$ & & Partial & $\begin{array}{l}\text { Full } \\
\text { identification }\end{array}$ & $\begin{array}{l}\text { Full } \\
\text { identification }\end{array}$ & $\begin{array}{l}\text { Full } \\
\text { identification }\end{array}$ \\
\hline $\begin{array}{l}\text { Sub-move I: Giving case } \\
\text { history }\end{array}$ & $\begin{array}{l}\text { Partial } \\
\text { identification }\end{array}$ & identification \\
\hline $\begin{array}{l}\text { Sub-move II: Presenting } \\
\text { arguments }\end{array}$ & $\begin{array}{l}\text { Partial } \\
\text { identification }\end{array}$ & $\begin{array}{l}\text { No } \\
\text { identification }\end{array}$ & $\begin{array}{l}\text { Partial } \\
\text { identification }\end{array}$ & $\begin{array}{l}\text { Full } \\
\text { identification }\end{array}$ & $\begin{array}{l}\text { No } \\
\text { identification }\end{array}$ \\
\hline $\begin{array}{l}\text { Sub-move III: Deriving } \\
\text { ratio decidendi }\end{array}$ & $\begin{array}{l}\text { No } \\
\text { identification }\end{array}$ & $\begin{array}{l}\text { No } \\
\text { identification }\end{array}$ & $\begin{array}{l}\text { Full } \\
\text { identification }\end{array}$ & $\begin{array}{l}\text { No } \\
\text { identification }\end{array}$ & $\begin{array}{l}\text { No } \\
\text { identification }\end{array}$ \\
\hline $\begin{array}{l}\text { Move 4: Pronouncing on } \\
\text { the judgement }\end{array}$ & $\begin{array}{l}\text { Full } \\
\text { identification }\end{array}$ & $\begin{array}{l}\text { Full } \\
\text { identification }\end{array}$ & $\begin{array}{l}\text { Full } \\
\text { identification }\end{array}$ & $\begin{array}{l}\text { Full } \\
\text { identification }\end{array}$ & $\begin{array}{l}\text { Partial } \\
\text { identification }\end{array}$ \\
\hline
\end{tabular}


claimed that the differences occurred because she was trying to explain further with more arguments rather than reading through the whole case. She only read what was important with regards to the case issue.

Student 2 was also able to identify several legal structures of the case law, but she did not complete the moves. Not only she did not identify Move 2, but she also did not identify sub-move II and III of Move 3. To student 2, there was no need to read everything in Move 3 as case understanding could be done by reading only the important information. Her justification may relate to the facts that in her lessons to read case law, she was taught to read both the headnotes section and full judgement. She noted that to understand what the case was about, she did not really need to read the full judgement. She was aware that the headnotes section provided her with pertinent information concerning the case, and the full judgement section of the case law provided the facts of the case and detailed information that she needed on how the judge had reached the decision. Even though she did not identify Move 2 and 3 she was still able to identify Move 4 . She further admitted the importance of knowing the case law structure. To understand the case law, she only needed to summarise the full judgement. She admitted that there was no difference in her case law reading behaviour, and the reading strategies lessons that she learned in her English classes were sufficient to help her in understanding the case law.

Like Student 1 and 2, Student 3 was also able to recognise Move 1, but she only identified the key features of the Move and did not identify all aspects. Then, she identified Move 2 and 3. Like Student 1, she only acknowledged the first part of sub-move II and III of Move 3. She recognised the second question and the arguments made by the judge, and the reasoning behind the judge decision, as well as the identification of the ratio decidendi. However, she did not recognise the arguments for the first question raised in the case. She completed her move by fully identifying Move 4 . She agreed that understanding text structure would help in understanding the case flow, and it would be confusing if she did not know the structure. This would have hindered her case law understanding. She stated that she did not read differently, but she claimed that her English classes helped her in understanding the case law. She would also talk to herself while trying to find the case facts as her main reading strategy.

Student 4 was aware of several case law's legal and structural signals like the headnotes section, the held section, and the full judgement of the case. She clearly identified Move 1, 2, 3 including Sub-move I and II and 4. Unlike the other students, she was the only student who could identify both issues raised in the case law. Interestingly, she did not manage to derive the ratio decidendi. She agreed that knowing the text structure would help her in identifying the facts and arguments put forward by counsels and the judgement. Her reading behaviour corroborated her data as she was able to identify Move 3 and 4. Furthermore, she stated that the strategy that she used to understand case law was to understand the facts and the main sources of the law applied in the case. However, she claimed that she did not utilise different reading strategies, and the reading strategies that she learned in the English classes were insufficient in understanding the case law.

Student 5 reading behaviour was marked with missing moves. She was the only participant who did not identify Move 1. She started her reading at the catchwords section and moved to Move 2. The same reading behaviour was also reflected in her Move 3 when she only recognised sub-move I. She said that the headnotes section of the case law was sufficient, and she chose not to read everything. Nevertheless, her reading behaviour showed confusion in identifying sub-move II and III of Move 3, and she was not able to fully identify Move 3. Although she managed to identify Move 4, her reading behaviour showed her difficulties in understanding the judgement. She acknowledged that she did not use any strategies, and she would usually read the case summary in the textbook before reading the case law. With regards to the question of the importance in knowing the structure of the text that she read, she stated that it could help her to acknowledge the details of the text, and to use the information for her arguments in subsequent cases. She also acknowledged that the reading strategies that she learned in her English classes only partially helped her as she was not taught on how to read case law in the English classes. Thus, she applied the same reading strategies when reading case law.

The data showed that majority of the students were not able to identify and complete Move 3 . Move 3 was a very complex and important part of the case law as it revealed the arguments posed by the counsels from the opposing parties. These arguments would be supported by the interpretation of statues and case law which would be the main reference for the students if they encountered similar case. Similarly, Noraini (1997) concurred that her research participants displayed the identification, and they were also aware of the importance of Move 3, but she did not investigate further on the extent of students' awareness on the structures. ${ }^{13}$ Holland \& Webb (2006) assented the fact that reading case law required skills and interpretation which were built through experience. ${ }^{14}$ The findings in this paper also corroborated with Lunderberg (1987) who also consented that case structure knowledge empowered the readers to distinguish between language that signals the germane point of the rationale and language that signals dicta (judicial ramblings). ${ }^{15}$ Genre awareness and knowing the case law structure were important for law students. 


\section{Conclusion}

The findings were intended to examine the level and extent of case law awareness among the foundation in law students. The findings revealed that the students demonstrated the knowledge of the rhetorical structure of a case law, but the level of awareness varied among the participants. Analysing students understanding of reading case law can help both the students and EAP educators. The sooner the foundation in law students achieve the skills to read legal genre like legal experts, the quicker they will succeed in the law school and in their future lives. A more comprehensive study can be done in relooking and revising the syllabus for the needs of exposing and teaching students how to read case law and other legal genre. Stratman (1990) highlights those legal educators have erroneously made the assumption that law students who enter law schools are fully equipped with sufficient literacy skills which are readily transferred to the legal texts. ${ }^{16}$ Thus, English for academic purposes practitioners and legal educators should contribute to the knowledge of reading a syllabus that can assist the students to read legal genre.

The study is only limited to the foundation/pre-university law students at Multimedia University, and as such the findings could not be generalised for all law students in other universities in Malaysia. It is hoped that this study can provide some insights into the reading behaviour of law students especially when reading case law.

\section{Data availability}

Underlying data

DANS: Easy Genre Awareness among Foundation in Law Students

https://doi.org/10.17026/dans-xnd-uts $8^{12}$

This project contains the following underlying data:

Data file: Data Submission Genre Awareness.odt

Data are available under the terms of the Creative Commons Zero "No rights reserved" data waiver (CC0 1.0 Public domain dedication).

\section{Author contributions}

Abdullah, S. was involved with the conceptualisation, formal analysis, methodology, data collection, write up of the original draft and review \& editing while Bhar S. K was involved with the write up, review and editing.

\section{Acknowledgment}

The authors wish to thank the Multimedia Foundation in Law students' participants for the supports of this study.

1. Candlin $\mathrm{CN}$, Bhatia VK, Jensen $\mathrm{CH}$ : Developing legal writing. Engl. Specif. Purp. 2002; 21(4): 299-320. Publisher Full Text

2. Swales JM: Genre Analysis. Cambridge: Cambridge University Press; 1990.

3. Bhatia VK: A genre-based approach to ESP material development. World Englishes. 1991; 10(2): 153-166. Publisher Full Text

4. Bhatia VK: Analysing genre: Language use in professional settings. London: Longman; 1993.

5. Bhatia VK: Worlds of written discourse: a genre-based view. London: Continuum; 2004.

6. Christensen LM: The paradox of legal expertise: A study of experts and novices reading the law. BYU Educ. \& L.J. 2008; 53(1): 53-87. Reference Source

7. Christensen LM: Legal reading and success in law school: An empirical study. Seattle University Law Review. 2007. 30(1). (26 February 2006). Reference Source

8. Ariffin $A$ : The reading of legal cases by Law undergraduates: Some problems and suggestions. Procedia. Soc. Behav. Sci. 2014; 134(2014): 109-118. Publisher Full Text
9. Ericsson KA, Simon HA: Verbal reports as data. Psychol. Rev. 1980; 87(3): 215-251.

Publisher Full Text

10. Decarlo M: Scientific inquiry in social work. 2018 Reference Source

11. TANG SUNG MOOI V TOO MIEW KIM: The Malayan Law Journal. $3 \mathrm{MLJ}$ 117, *; [1994] $3 \mathrm{MLJ} 117$.

12. Abdullah, Senior Lecturer $S$ (Multimedia University): Genre Awareness among Foundation in Law Students. DANS. 2021 Publisher Full Text

13. Ibrahim N: Reading legal cases: An ethnographic enquiry. Thesis Master. Universiti Malaya. 1997.

14. Holland J, Webb J: Learning legal rules.6th ed. Oxford: Oxford University Press; 2006.

15. Lundeberg M: Metacognitive aspects of reading comprehension: Studying understanding in legal case analysis. Read. Res. Q. 1987; 22: 407-432. Publisher Full Text

16. Stratman JF: The emergence of legal composition as a field of inquiry: Evaluating the prospects. Rev. Educ. Res. 1990; 60: 153-235.

Publisher Full Text 


\section{Open Peer Review}

\section{Current Peer Review Status: ?}

\section{Version 1}

Reviewer Report 01 February 2022

https://doi.org/10.5256/f1000research.77282.r119450

(C) $2022 \mathrm{Ab}$ Rahim I. This is an open access peer review report distributed under the terms of the Creative Commons Attribution License, which permits unrestricted use, distribution, and reproduction in any medium, provided the original work is properly cited.

\section{Ina Suryani Ab Rahim}

Centre for International Languages (CIL), Universiti Malaysia Perlis, Arau, Malaysia

This paper reports on important issue of reading awareness among Law students, particularly on case law genre. The focus is on Foundation students, who are just beginning to develop a taste in reading legal texts which later will be very beneficial to the students of law. In addition to using a highly credible move model by Bhatia, the study also has obtained the appropriate ethical approval and consent.

The paper reports that the students demonstrated the knowledge of the rhetorical structure of case law, but the level of awareness varied among the participants. Perhaps this study is a part of a bigger study, which explains why the frequency pattern for the moves across the 5 readers remains ambiguous. Because data has not reached a saturation point due to small size of sampling, the conclusion for the finding has to be tactfully written. Having a size of five readers to test the protocol procedures and the potential of using Bhatia's move model is a justified choice. However, the size of five is not to be used as conclusion to generalize the knowledge of the foundation group of students, even for foundation/pre-university law students at Multimedia University as claimed in last paragraph of the paper "The study is only limited to the foundation/pre-university law students at Multimedia University...". Because of the small size, rather than claiming that the finding describes the way of reading for the foundation law students in $\mathrm{MMU}$ as in the last paragraph of the paper, it is safer to reassert the claim made in the initial part of the paper that limits the finding to the participants in the study. The data is not conclusive as it did not reach saturation for the group so it is questionable that the conclusion of the findings provides insights into the reading behaviour of foundation law students in MMU especially when reading case law. It is suggested that this claim is reworded and hedging is used.

Brief explanation on each move in Bhatia's model would also enhance the paper in terms of clarity. Given the potential for future study using bigger sampling, it is suggested that future analysis is presented in a thematic style, according to the fulfilment of the moves rather than explaining each of the students' experiences as done in this study. The paper also need to have more recent works related to the topic. 
Overall, the paper is useful and supports better understanding for English for academic purposes practitioners and legal educators.

Is the work clearly and accurately presented and does it cite the current literature? Partly

Is the study design appropriate and is the work technically sound?

Yes

Are sufficient details of methods and analysis provided to allow replication by others? Yes

If applicable, is the statistical analysis and its interpretation appropriate? Partly

Are all the source data underlying the results available to ensure full reproducibility? Yes

Are the conclusions drawn adequately supported by the results? Partly

Competing Interests: No competing interests were disclosed.

Reviewer Expertise: Genre analysis, English for Academic Purpose

I confirm that I have read this submission and believe that I have an appropriate level of expertise to confirm that it is of an acceptable scientific standard, however I have significant reservations, as outlined above.

The benefits of publishing with F1000Research:

- Your article is published within days, with no editorial bias

- You can publish traditional articles, null/negative results, case reports, data notes and more

- The peer review process is transparent and collaborative

- Your article is indexed in PubMed after passing peer review

- Dedicated customer support at every stage

For pre-submission enquiries, contact research@f1000.com

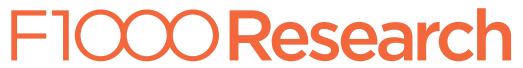

